\title{
DIVERSITY OF HERPETOFAUNA AND MAMMALS ON RECLAMATION LAND PT. REFINED BANGKA TIN BANGKA
}

\author{
Ratna Sari Hasibuan ${ }^{1}{ }^{*}$, Ken Dara Cita $^{1)}$, Suwandi Raharjo ${ }^{2)}$, Agus Seftian Pracahyo ${ }^{2)}$, \\ Fari Indarto ${ }^{3)}$ and Tanya Zurmie ${ }^{3)}$ \\ 1) Fakultas Kehutanan, Universitas Nusa Bangsa \\ Jl.KH Sholeh Iskandar Km 4, Tanah Sareal, Bogor 16166, Indonesia \\ ${ }^{2)}$ BSC Consulting (PT. Batata Sistem Caraka) \\ Jl. TB Simatupang, Talavera Office Park 28th Floor, Kav 22-26, Cilandak, Jakarta 12430, Indonesia \\ ${ }^{3)}$ PT.Refined Bangka Tin, Sungailiat Bangka \\ JL Jenderal Sudirman, Kav. 52-53, SCBD, Karet Tengsin, Jakarta 12190, Indonesia
}

\section{ARTICLE INFO \\ Article history: \\ Received 11 Feb 2021 , \\ Revised 04 Mei 2021, \\ Accepted 14 Jun 2021 \\ Available online 30 July 2021

$$
\begin{aligned}
& \text { Keywords: } \\
& \begin{aligned}
\checkmark & \text { herpetofauna } \\
\checkmark & \text { diversity } \\
\checkmark & \text { reclaimed land } \\
\checkmark & \text { mammals }
\end{aligned}
\end{aligned}
$$

*corresponding author: ratnasylva@gmail.com Phone: +62 ;

Doi:

https://doi.org/10.31938/jsn.v $\underline{11 \mathrm{i} 2.296}$

\section{ABSTRACT}

The success indicators of land reclamation can be seen in the presence of plants and animals. The more types of plants and animals that can live and reproduce, the better the condition of the land ecosystem. One of the indicators is the presence of herpetofauna and mammals, so this study aims to determine the diversity of wild animals consisting of herpetofauna, in this case, are reptiles and amphibians, and to determine the diversity of mammals in the area of PT. Refined Bangka Tin (PT. RBT). The research method was the Visual Encounter Survey (VES) for collecting herpetofauna data and the Path Transect method for collecting data on mammals. The results showed that seven species of reptiles were found with a diversity of 1.51, while there were three types of amphibians with a diversity of 1.04. The diversity of reptiles and amphibians based on the Shannon-Wiener diversity index is moderate. There are four species of mammals with a diversity of 1.12 based on the Shannon-Wiener diversity index value that the diversity of mammals is moderate.

\section{ABSTRAK \\ Keanekaragaman herpetofauna dan mamalia pada lahan reklamasi PT. Refined Bangka Tin, Bangka}

Suatu perusahaan dikatakan berhasil mengelola lahan reklamasinya ditandai dengan adanya flora dan fauna. Semakin tinggi keanekaragaman flora dan fauna pada lahan reklamasi maka semakin baik keadaan ekosistem pada lahan reklamasi tersebut. Salah satu fauna yang terdapat pada lahan reklamasi adalah herpetofauna dan mamalia, sehingga tujuan dari penelitian ini adalah untuk mengetahui keanekaragaman satwa liar yang terdiri dari herpetofauna dalam hal ini adalah reptil dan amfibi serta untuk mengetahui keanekaragaman mamalia di kawasan PT. Refined Bangka Tin (PT. RBT). Metode penelitian adalah Visual Encounter Survey (VES) untuk pengambilan data herpetofauna dan metode Transek Jalur untuk pengambilan data mamalia. Hasil penelitian adalah satwa reptil ditemukan sebanyak 7 jenis dengan keanekaragaman 1,51, sedangkan amfibi ditemukan sebanyak 3 jenis dengan keanekaragaman sebesar 1,04. Keanekaragaman reptil dan amfibi yang berdasar pada indeks keanekaragaman Shannon-Wiener adalah sedang. Satwa mamalia ditemukan sebanyak 4 jenis dengan keanekaragaman sebesar 1,12 termasuk sedang berdasar nilai indeks keanekaragaman Shannon-Wiener.

Kata kunci : herpetofauna, keanekaragaman, lahan reklamasi, mamalia 


\section{PENDAHULUAN}

PT. Refined Bangka Tin (RBT) terletak di Sungai Liat bergerak di bidang pengolahan dan pemurnian timah. Kegiatan penambangan di PT.RBT secara umum menggunakan sistem penambangan terbuka atau open pit mining. Open pit mining dilakukan dengan pengupasan topsoil dan bahan tambang digali, diangkut ke tempat penampungan (stockyard) kemudian dimanfaatkan sebagai bahan baku industry (Subowo, 2011) . Akibat penambangan yang dilakukan, terjadi kerusakan lingkungan seperti hilangnya flora fauna, hilangnya unsur makro tanah seperti unsur Nitrogen, Pospor, Kalium, unsur mikro tanah seperti unsur Besi, Mangan, Tembaga, Seng dan lain-lain, terjadinya erosi tanah, perubahan kepadatan tanah, peningkatan zat yang bersifat toxic pada tanah, polusi air dan polusi udara.

PT. RBT melakukan penanaman pada lahan reklamasi dengan tanaman sengon (Paraserianthes falcataria L.). Subowo (2011) menjelaskan tanaman Legum seperti Sengon dapat mengikat gas Nitrogen yang bersimbiosis dengan bakteri Rhizobium, dan menghasilkan unsur hara makro di tanah sehingga dapat mempercepat pemulihan kesuburan tanaman.. Sengon (Paraserianthes falcataria L.) merupakan jenis pioner yang menjadi pilihan untuk ditanam di area reklamasi berkelanjutan Kegiatan penanaman kembali area reklamasi berkelanjutan yang semula kosong memiliki tujuan untuk mengembalikan kehadiran fauna untuk beraktivitas di area reklamasi berkelanjutan tersebut. Keberadaan flora fauna pada lahan reklamasi dapat menjadi indikator keberhasilan pemulihan lahan reklamasi. Semakin besar keanekaragaman tumbuhan dan satwa yang dapat hidup dan berkembang biak, maka semakin baik keadaan ekosistem lahan tersebut.

Peran satwa dalam hal ini herpetofauna dan mamalia dalam suatu ekosistem cukup penting, dalam aspek ekologis (Kusrini, 2009). Dalam aspek ekologis, herpetofauna dan mamalia berperan sebagai indikator lingkungan dan menjaga keseimbangan ekosistem. Pada sistem rantai makanan di suatu ekosistem, Herpetofauna berperan sebagai predator dan merupakan bioindikator terhadap perubahan lingkungan. Sedangkan dalam hal menyuburkan tanah, menyebarkan biji, penyerbukan bunga, dan pengendali hama/penyakit peran mamalia sangatlah besar (Hasibuan et al., 2018). Tujuan dari penelitian ini adalah mengetahui keanekaragaman herpetofauna dalam hal ini adalah Reptil dan Amfibi serta untuk mengetahui keanekaragaman mamalia di kawasan PT. RBT.

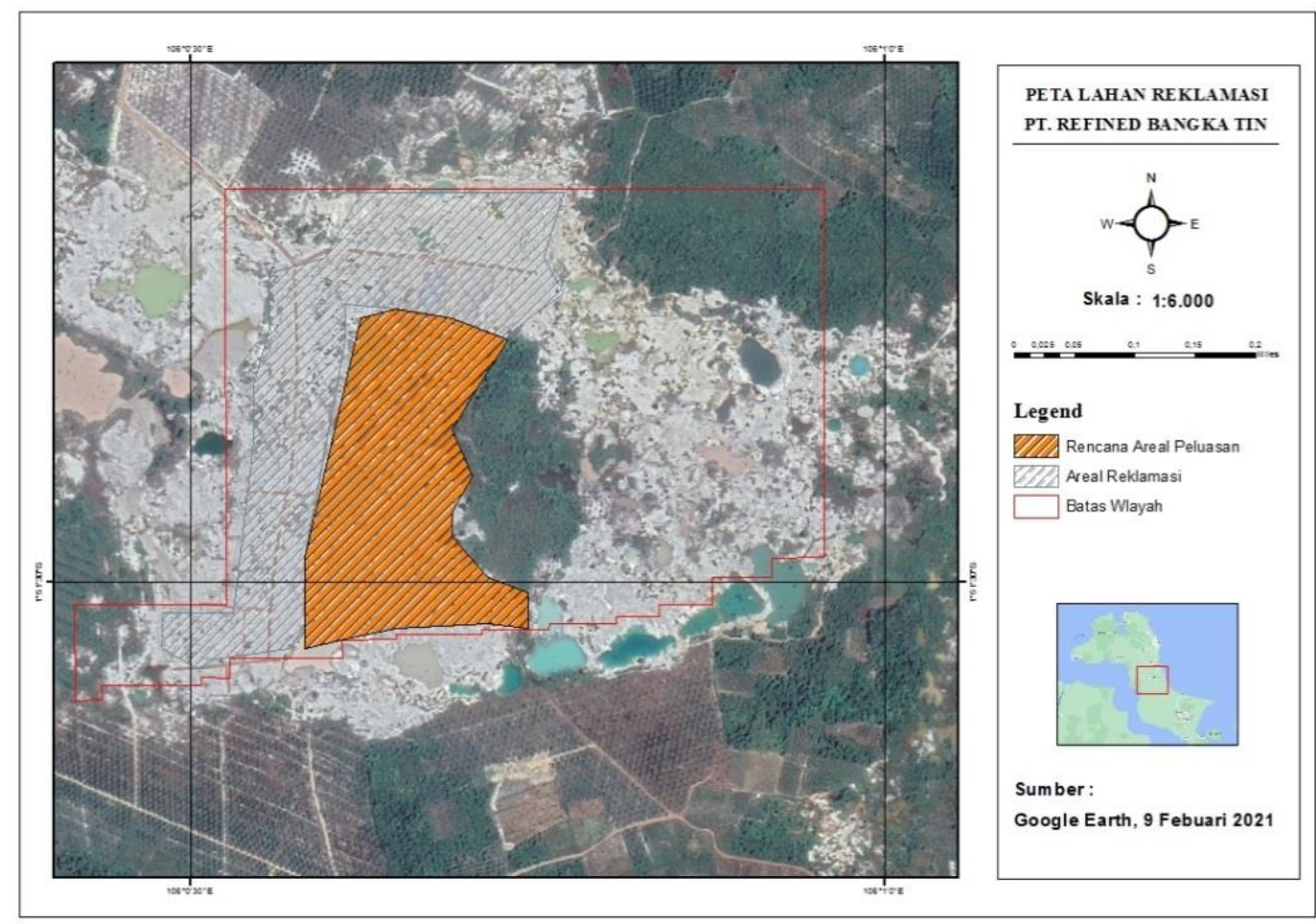

Gambar 1. Lokasi Penelitian di lahan reklamasi PT.RBT 


\section{BAHAN DAN METODE}

\section{Bahan dan Alat}

Alat yang digunakan adalah Peta lahan reklamasi PT.RBT, headlamp/senter, kompas, GPS (Global Position System), binokuler, alat tulis, kamera, buku panduan identifikasi herpetofauna dan mamalia.

\section{Metode}

Penelitian dilakukan bulan Januari-Februari 2021 pada kawasan reklamasi berkelanjutan PT. RBT seluas 23.2 ha. Lokasi penelitian di Desa Penyamun, Kecamatan Pemali, Kabupaten Bangka (Gambar 1 Peta lokasi penelitian). Secara umum metode yang digunakana pada penelitian ini adalah Visual Encounter Survey (VES) (Heyer et al., 1994) dan metode jalur (transek sampling) (Kusrini, 2009).

Pengambilan data herpetofauna dan mamalia dilakukan dengan pengamatan langsung dan tidak langsung dengan Intensitas sampling $10 \%$ dari luasan lahan reklamasi PT. RBT yang dilakukan secara purposive sampling. Pengamatan langsung dilakukan dengan menjumpai secara langsung individu yang teramati. Pengamatan secara tidak langsung dilakukan dengan merekam suara satwa, feces, bekas cakaran atau jejak.

\section{Herpetofauna}

Metode untuk pengamatan herpetofauna menggunakan Metode Visual Encounter Survey (VES) (Heyer et al., 1994) dikombinasikan dengan sistem jalur (transek sampling) yang peletakkannya dilakukan secara purposive berdasarkan dua tipe habitat yaitu aquatik dan terestrial (Kusrini, 2009). Gambar 2 merupakan ilustrasi pengamatan herpetofauna. Pengamatan pada pagi pukul 07.00-10.00 dan malam pukul 19.00-22.00. Pengamatan pagi hingga siang hari dilakukan untuk mengidentifikasi jenis amfibi dan reptil yang aktif pada pagi atau siang hari (diurnal).

\section{Mamalia}

Metode yang digunakan pada pengamatan mamalia dilakukan dengan metode transek jalur. Panjang rata-rata jalur $\pm 1000 \mathrm{~m}$ dan setiap lokasi penelitian dibuat 2 jalur pengamatan. Arah jalur transek dengan lebar $35 \mathrm{~m}$ kiri kanan di sesuaikan dengan kondisi lapangan (Gambar 3). Pengamatan dilakukan dua kali sehari pada pagi hari pukul 07.00-09.00 dan sore hari 15.30-18.00, pencatatan data melalui kontak langsung ataupun tidak langsung, meliputi pencatatan perjumpaan jejak kaki, tempat untuk bersarang, kotoran atau feses dan bekas lain yang ditinggalkan.

\section{Analisa Data}

Data yang diperoleh akan dianalisa dan diuraikan dalam bentuk deskriptif yaitu berdasarkan keanekaragaman dengan indeks Shannon Wiener dan keseragaman jenis. Uraian deskripsi juga dilakukan terhadap status konservasi herpetofauna dan mamalia.

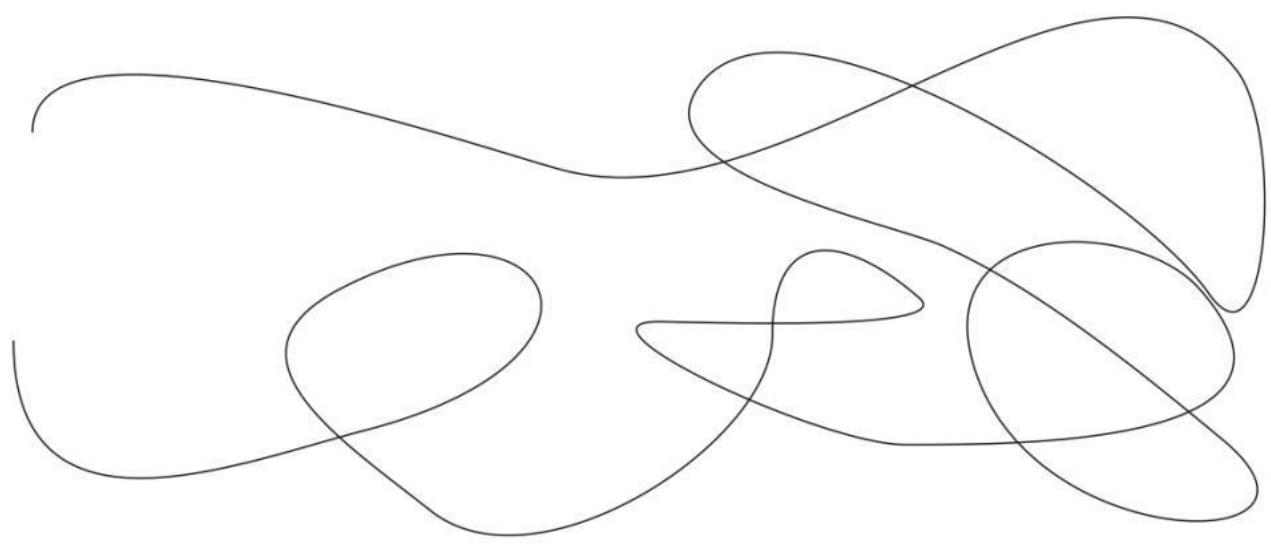

Gambar 2. Metode VES (Visual Encounter Survey) 


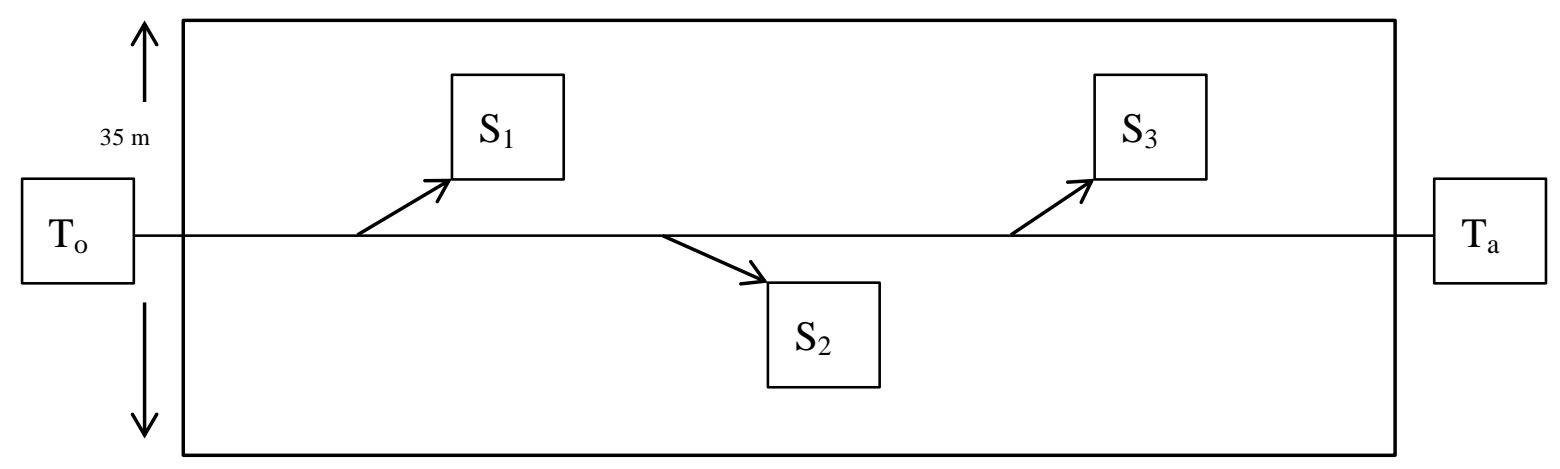

Keterangan $: \mathrm{T}_{\mathrm{o}}=$ Titik awal, $\mathrm{T}_{\mathrm{a}}=$ titik akhir, $\mathrm{S}=$ Posisi jejak satwa liar Gambar 3. Sketsa Transek Jalur

Tabel 1. Klasifikasi nilai indeks keanekaragaman Shannon-Wiener

\begin{tabular}{cl}
\hline Nilai indeks Shanon & \multicolumn{1}{c}{ Kategori } \\
\hline$>3$ & $\begin{array}{l}\text { Keanekaragaman tinggi, penyebaran jumlah individu Tiap } \\
\text { spesies tinggi dan kestabilan komunitas tinggi }\end{array}$ \\
& $\begin{array}{l}\text { Keanekaragaman sedang, penyebaran jumlah individu Tiap } \\
\text { spesies sedang dan kestabilan komunitas sedang } \\
\text { Keanekaragaman rendah, penyebaran jumlah individu Tiap } \\
\text { spesies rendah dan kestabilan komunitas rendah }\end{array}$ \\
&
\end{tabular}

Sumber: Magurran AE (1988)

\section{Keanekaragaman Jenis}

Indeks Keanekaragaman Jenis ShannonWiener digunakan untuk mengetahui kelimpahan jenis dengan rumus Indeks Keanekargaman Jenis Shannon-Wiener (Magurran, 1988).

$$
\mathrm{H}^{\prime}=-\sum \frac{n}{N} \ln \frac{n}{N}
$$

Keterangan: $\quad H^{\prime}=$ Indeks Keanekaragaman Jenis

$$
\ln =\text { Logaritma natural }
$$

$\mathrm{n}=$ Jumlah individu tiap jenis

$\mathrm{N}=$ Jumlah total individu seluruh jenis

Untuk menentukan keanekaragaman jenis herpetofauna dan mamalia, maka digunakan klasifikasi nilai indeks keanekaragaman ShanonWieners dapat dilihat pada Tabel 1.

\section{Keseragaman Jenis}

Nilai keseragaman jenis dihitung menggunakan Indeks Keseragaman Jenis dengan rumus (Ludwig \& Reynolds, 1988) sebagai berikut:

$$
\mathbf{E}=\frac{\boldsymbol{H}^{\prime}}{\operatorname{Ln} S}
$$

\section{Dimana}

$$
\begin{aligned}
& \mathrm{E}=\text { Indeks keseragaman jenis } \\
& \mathrm{S},=\text { Jumlah jenis } \\
& \mathrm{H}^{\prime} \quad \text { Indeks keanekaragaman jenis }
\end{aligned}
$$

Kisaran nilai Indeks Keseragaman ShannonWiener (E) :

$0<\mathrm{E}<0,5=$ Komunitas dalam keadaan tertekan

$0,5<\mathrm{E}<0,75=$ Komunitas dalam keadaan agak seimbang

$0,75<\mathrm{E}<1=$ Komunitas dalam keadaan seimbang

\section{Kekayaan jenis}

Untuk mengetahui kekayaan jenis Margalef dihitung dengan menggunakan rumus kekayaan jenis yaitu :

\section{Dmg $=$ S-1/In N}

Keterangan :

Dmg = Indeks kekayaan jenis Margalef

$\mathrm{N}=$ Jumlah individu semua jenis

$\mathrm{S} \quad=$ Jumlah jenis yang ditemukan

Nilai tolak ukur indeks kekayaan jenis Margalef yaitu:

Dmg $<3,5=$ Maka kekayaan jenis rendah

$3,5<$ Dmg $<5=$ Maka kekayaan jenis sedang

Dmg $>5 \quad=$ Maka kekayaan jenis tinggi 


\section{HASIL DAN PEMBAHASAN}

\section{Herpetofauna}

Herpetofauna terdiri dari satwa jenis reptil dan amfibi. Jenis satwa Reptil yang ditemukan ada tujuh jenis (Tabel 2). Menurut Goin et al (1978) reptil merupakan jenis satwa melata yang bertulang beakang dan berdarah dingin. Kelompok reptil tergolong ke dalam satwa ectothermic atau suhu tubuh satwa tersebut sangat dipengaruhi oleh suhu di lingkungan sekitarnya oleh karenanya, satwa tersebut sangat membutuhkan sumber panas dari luar tubuhnya untuk dapat beraktivitas secara normal. Satwa ini tidak memiliki rambut atau bulu, tetapi memiliki tubuh yang dilapisi oleh sisik yang merata. Sisik ini berfungsi untuk mengatur sirkulasi air melalui kulitnya. Kulit reptil bersifat impermeable (tidak tembus air) yang menjadi sisik dan berfungsi untuk mengurangi hilangnya cairan tubuh, sehingga dapat memungkinkan beberapa jenis reptil bertahan hidup di daerah padang pasir. Reptil dapat mengatur suhu tubuhnya menjadi konstan sehingga dapat beraktifitas walaupun terpapar sinar matahari dan panas dari tanah (Sukiya, 2003). Jenis reptil seperti kadal menjemur tubuhnya pada siang hari dengan tujuan memperoleh suhu panas yang optimal, sedangkan pada kondisi suhu yang dingin, satwa ini masuk ke dalam lubang untuk tetap mengatur panas tubuhnya (Cogger, 1999). Satwa reptil banyak ditemukan di sekitar kolamkolam (kolong) yang ada di lahan reklamasi PT. RBT seperti jenis-jenis kadal.

Salah satu reptil yang ditemukan adalah biawak air (Varanus salvator). Satwa ini merupakan satwa endemik di Indonesia berukuran sekitar 1 sampai 2 meter. Biawak air merupakan jenis kadal terbesar kedua setelah komodo yang sering terlihat keluar dari air dan berjalan di sekitar sumber air (kolong). Bagi biawak air (Gambar 4), kolong merupakan tempat sumber pakan karena adanya ikan, jangkrik, siput, katak, dan telur burung (Nurkharimah, 2019). Secara ekonomis, kulit biawak air dapat digunakan untuk membuat kerajinan tas, dompet, sedangkan dagingnya untuk konsumsi dan obat seperti obat asam urat, obat luka bakar, obat gatal-gatal dan menghaluskan kulit.

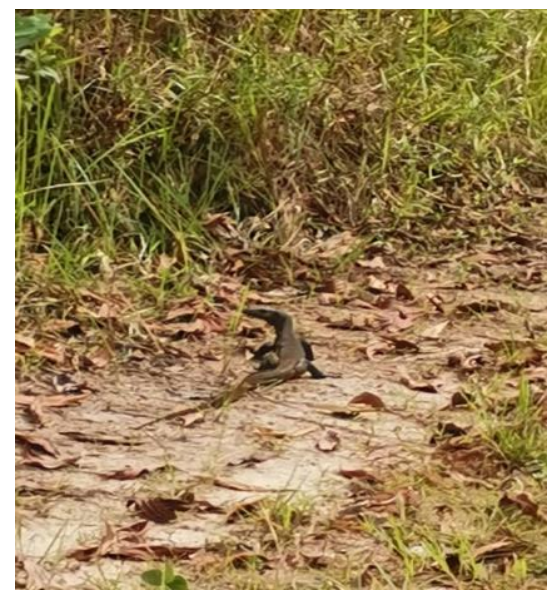

Gambar 4. Biawak Air di Lokasi Reklamasi PT. RBT desa Penyamun Sungailiat
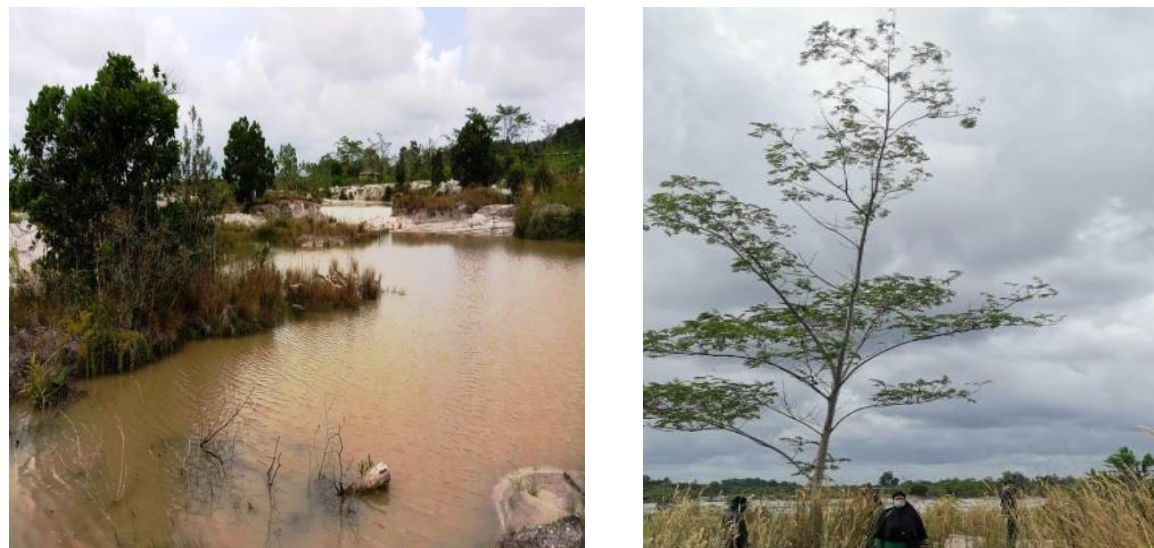

Gambar 5. Kondisi di Lokasi Penelitian Lahan Reklamasi PT. RBT Desa Penyamun Sungailiat 
Tabel 2. Kenaekaragaman jenis Reptil dilokasi reklamasi PT. RBT

\begin{tabular}{ccccccc}
\hline No & Nama Jenis & Nama Latin & Total & pi & H' & E \\
\hline 1 & Kadal kebun & Eutropis mutifasciata & 1 & 0,06 & 0,17 & 0,09 \\
2 & Kadal serasah & Eutropis rudis & 1 & 0,06 & 0,17 & 0,09 \\
3 & Biawak air & Varanus salvator & 2 & 0,12 & 0,25 & 0,13 \\
4 & Cicak rumah & Hemidactylus frenatus & 9 & 0,53 & 0,34 & 0,17 \\
5 & Cicak pohon & Gehyra mutilata & 2 & 0,12 & 0,25 & 0,13 \\
6 & Ular pucuk & Ahaetulla prasina. & 1 & 0,06 & 0,17 & 0,09 \\
7 & Ular tanah & Coelognathus radiatus & 1 & 0,06 & 0,17 & 0,09 \\
& & 17 & 1,00 & 1,51 & 0,77 \\
\hline
\end{tabular}

Keterangan : P $i=$ Proporsi Nilai Penting, $H^{\prime}=$ Indeks Keanekaragaman Jenis, $E=$ Indeks keseragaman jenis.

Hasil penelitian (Tabel 2), terdapat 7 jenis reptil dengan keanekaragamannya sebesar 1,51 termasuk sedang berdasar nilai indeks keanekaragaman Shannon-Wiener, hal ini berbeda dengan hasil penelitian Muslim \& Ulfah (2016) dengan keanekaragaman reptil rendah kisaran 0 - 1,33. Penelitian ini dilakukan pada lahan reklamasi tambang batubara PT. Singlurus Pratama, Kalimantan Timur.

Perbedaan jumlah keanekaragaman dikarenakan berbedanya loksi penelitian, dimana lokasi penelitian dilahan reklamasi PT. RBT ada sekitar 4 sumber air, sehingga banyak reptil ditemukan disekitar kolong tersebut dan tutupan tajuk pohon sengon yang sudah berumur sekitar 3 tahun dapat melindungi reptil dari sengatan matahari (Gambar 5). Keseragaman jenis pada lokasi penelitian termasuk agak seimbang yaitu 0,77 berdasar kisaran nilai indeks keseragaman Shannon-Wiener dengan satwa yang paling dominan adalah cicak rumah (Hemidactylus frenatus). Kekayaan jenis dari hasil penelitian sebesar 6,65 dengan merujuk indeks kekayaan jenis Margalef termasuk tinggi.

Selain reptil, amfibi juga merupakan hewan yang termasuk ke dalam Herpetofauna. Hasil penelitian (Tabel 3) menunjukkan ada tiga jenis amfibi yang ditemukan. Menurut Duellman \& Trueb (1986) amfibi merupakan satwa vertebrata (bertulang belakang) yang memiliki ciri berupa kelenjar pada kulit, berkaki empat dan tidak memiliki struktur epidermal. Amfibi merupakan hewan yang hidup di dua alam yaitu darat dan air, dimana amfibi berasal dari kata amphi artinya ganda dan bio artinya hidup. Pada bangsa Anura terdiri dari katak dan kodok. Ciri dari kedua jenis ini yaitu memiliki empat kaki, mata cenderung lebih besar dan tidak berekor. Amfibi mengalami metamorfosis sempurna yaitu mulai dari berudu bernafas dengan menggunakan insang dan setelah dewasa bernafas dengan paruparu dengan memiliki kaki terdiri dari 4 jari dan belakang 5 jari. Ada beberapa yang membedakan jenis kodok atau katak. Untuk jenis kodok ukuran tubuhnya cenderung lebih besar dibandingkan jenis katak. Pada jenis-jenis kodok (Bufonidae) memiliki tekstur kulit yang sangat kasar, berbeda dengan katak yang permukaan kulitya halus. Pada jenis katak, terdapat selaput pada bagian kaki yang berfungsi untuk memudahkan katak berenang. Berbeda dari jenis katak, pada kodok terdapat bejolan pada kulit yang bernama kelenjar paratoid. Jenis-jenis amfibi hidup didua alam dan merupakan jenis yang aktif pada siang (diurnal) serta malam hari (nocturnal). Sebagian besar amfibi hidup pada malam hari (nocturnal) (Heyer et al., 1994; Ariza et al., 2014).

Tabel 3. Jenis Amfibi yang ditemukan pad lahan reklamasi PT. RBT Sungailiat Bangka

\begin{tabular}{cllcccc}
\hline No & Nama Jenis & \multicolumn{1}{c}{ Nama Latin } & Total & pi & H' & E \\
\hline 1 & Kodok sawah & Fejervarya cancrivora & 1 & 0,25 & 0,35 & 0,32 \\
2 & Kodok tegalan & Fejervarya limnocharis & 2 & 0,50 & 0,35 & 0,32 \\
3 & Kodok Puru & Phrynoidis melanostictus & 1 & 0,25 & 0,35 & 0,32 \\
& & & 4 & 1,00 & 1,04 & 0,95 \\
\hline
\end{tabular}

Keterangan : Pi =Proporsi Nilai Penting, $H^{\prime}=$ Indeks Keanekaragaman Jenis, $E=$ Indeks keseragaman jenis 
Hasil penelitian menunjukkan keanekaragaman amfibi sebesar 1,04 (Tabel 3), yang berdasar pada indeks keanekaragaman ShannonWiener keanekaragaman sedang, penyebaran jumlah individu Tiap spesies sedang dan kestabilan komunitas sedang. Faktor-faktor yang mempengaruh tinggi rendahnya keanekaragaman, keseragaman dan kekayaan jenis suatu satwa adalah dengan adanya kelimpahan pakan, kondisi ekosistem seperti bencana alam, cuaca ekstrim dan aktivitas manusia.

Keseragaman jenis amfibi adalah 0,95 dimana komunitas dalam keadaan seimbang dengan kekayaan jenis (Dmg) sebesar 2,28 berdasar indeks kekayaan jenis Margalef termasuk rendah. Hal ini kemungkinan disebabkan pada saat penelitian tidak terjadinya hujan sehingga banyak kodok yang tidak kelihatan. Jenis-jenis kodok (Bufonidae) sangat menyukai kondisi lingkungan yang lembab, basah dan hujan (Gambar 6), karena saat hujan serangga yang merupakan makanan kodok akan keluar sehingga pakan dari kodok tersebut melimpah (Sanhayani et al., 2019; Kwatrina, 2019). Keadaan lingkungan berpengaruh terhadap keberadaan amfibi. Penutupan vegetasi sangat berperan baik itu penutupan vegetasi secara vertikal maupun horizontal karena peranannya dalam hal intensitas cahaya matahari yang akan sampai ke lantai hutan. Kelembaban dan suhu pada berbagai tutupan lahan akan mempengaruhi keberadaan amfibi (Muslim \& Ulfah, 2016).

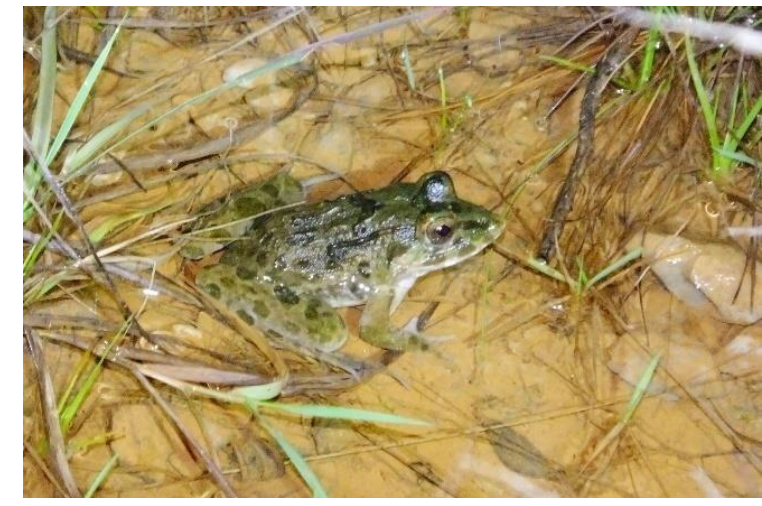

Gambar 6. Kodok Sawah (Fejervarya cancrivora) yang ditemukan pada lahan reklamasi PT. RBT Sungailiat Bangka

Hasil penelitian pada Tabel 4 bahwa herpetofauna (Reptil dan Amfibia) secara keseluruhan status perlindungannya berdasar Peraturan Menteri Lingkungan Hidup Dan Kehutanan No 106 (2018), tidak termasuk satwa yang dilindungi. Berdasar kategori IUCN, satwa-satwa herpetofauna yang ditemukan saat penelitian Least Concern (LC; Berisiko Rendah) adalah kategori IUCN yang diberikan untuk spesies yang telah dievaluasi namun tidak masuk ke dalam kategori manapun. Untuk satwa biawak air (Varanus salvator) berdasar CITES (status perdagangan satwa) bahwa biawak air termasuk apendiks 2 yaitu spesies yang tidak selalu terancam kepunahannya, tetapi untuk menghindari pemanfaatan yang membahayakan kelangsungan hidupnya maka pemanfaatannya harus dikontrol.

Tabel 4. Status perlindungan herpetofauna dilahan reklamasi PT. RBT

\begin{tabular}{|c|c|c|c|c|c|}
\hline \multirow{2}{*}{ No } & \multirow{2}{*}{ Nama Jenis } & \multirow{2}{*}{ Nama Latin } & \multicolumn{3}{|c|}{ Status Perlindungan } \\
\hline & & & P 106/2018 & IUCN & CITES \\
\hline 1 & Kodok sawah & Fejervarya cancrivora & TD & LC & NA \\
\hline 2 & Kodok tegalan & Fejervarya limnocharis & TD & LC & NA \\
\hline 3 & Kodok Puru & Phrynoidis melanostictus & TD & LC & NA \\
\hline 4 & Kadal kebun & Eutropis mutifasciata & $\mathrm{TD}$ & LC & NA \\
\hline 5 & Kadal serasah & Eutropis rudis & $\mathrm{TD}$ & LC & NA \\
\hline 6 & Biawak air & Varanus salvator & $\mathrm{TD}$ & LC & II \\
\hline 7 & Cicak rumah & Hemidactylus frenatus & $\mathrm{TD}$ & LC & NA \\
\hline 8 & Cicak pohon & Gehyra mutilata & $\mathrm{TD}$ & LC & NA \\
\hline 9 & Ular pucuk & Ahaetulla prasina & $\mathrm{TD}$ & LC & NA \\
\hline 10 & Ular tanah & Coelognathus radiatus & $\mathrm{TD}$ & LC & NA \\
\hline
\end{tabular}

Keterangan: $T D=$ tidak dilindungi; $L C=$ least concern; $N A=$ non-appendix 
Tabel 5. Mamalia yang ditemukan dilahan Reklamasi PT. RBT Desa Penyamun Sungailiat Bangka

\begin{tabular}{cllcccc}
\hline No & Nama Jenis & \multicolumn{1}{c}{ Nama Latin } & Total & pi & $\mathbf{H}^{\prime}$ & $\mathbf{E}$ \\
\hline 1 & Bajing kelapa & Callosciurus notatus & 10 & 0,59 & 0,31 & 0,22 \\
2 & Celurut rumah & Suncus murinus & 2 & 0,12 & 0,25 & 0,18 \\
3 & Musang Luwak & Paradoxurus hermaphroditus & 2 & 0,12 & 0,25 & 0,18 \\
4 & Kelelawar & Vespertilionidae & 3 & 0,18 & 0,31 & 0,22 \\
& & & 17 & 1,00 & 1,12 & 0,81 \\
\hline
\end{tabular}

Keterangan : Pi =Proporsi Nilai Penting, $H^{\prime}=$ Indeks Keanekaragaman Jenis, , E = Indeks keseragaman jenis

Tabel 6. Status Perlindungan Mamalia di areal reklamasi PT. RBT

\begin{tabular}{cllccc}
\hline \multirow{2}{*}{ No } & \multirow{2}{*}{ Nama Jenis } & \multirow{2}{*}{ Nama Latin } & \multicolumn{3}{c}{ Status Perlindungan } \\
\cline { 3 - 5 } & & & P 106/2018 & IUCN & CITES \\
\hline 1 & Bajing kelapa & Callosciurus notatus & TD & LC & NA \\
2 & Celurut rumah & Suncus sp. & TD & LC & NA \\
3 & Musang Luwak & Paradoxurus hermaphroditus & TD & LC & NA \\
4 & Kelelawar & Vespertilionidae & TD & LC & NA \\
\hline
\end{tabular}

Keterangan: $T D=$ tidak dilindungi; $L C=$ least concern; $N A=$ non-appendix

\section{Mamalia}

Mamalia adalah hewan menyusui yang memiliki peranan dalam ekosistem. Mamalia dapat menyeimbangkan ekosistem dan berperan dalam menyebarkan biji seperti pada hewan musang, menyuburkan tanah, penyerbukan bunga, dan pengendali hama/penyakit seperti pada hewan kelelawar. Hasil peneltian yang dilakukan pada lahan reklamasi PT. RBT desa Penyamun Sungailiat terlihat bahwa terdapat 4 jenis hewan mamalia yang ditemukan dengan keanekaragaman sebesar 1,12 (Tabel 5), berdasar nilai indeks keanekaragaman Shannon-Wiener bahwa keanekaragaman mamalia termasuk sedang, dimana kestabilan komunitas sedang dan penyebaran jumlah individu tiap spesies sedang. Hal ini berbeda dengan keanekaragaman mamalia yang ditemukan pada lahan reklamasi PT. ANTAM, dimana berdasar indeks ShannonWiener keanekaragaman mamalia diantara 0,64 sampai 1,25 , yaitu rendah sampai sedang. Hal ini dikarenakan mamalia yang datang ke areal reklamasi PT. ANTAM lebih banyak untuk mencari makan, karena adanya sisa makanan dari manusia (pekerja) seperti yang dilakukan oleh monyet ekor panjang, sedangkan satwa tersebut bertempat tinggal di Taman Nasional Halimun Salak, yang loksinya berdekatan dengan areal reklamasi (Hasibuan et al., 2018).

Berdasar indeks kekayaan jenis Margalef kekayaan jenis mamalia di lahan rekalamasi PT. RBT termasuk sedang yaitu 3,65 dengan nilai Indeks Keseragaman Shannon-Wiener (E) termasuk seragam yaitu 0.81 dan jenis mamalia yang dominan adalah bajing kelapa. Bajing kelapa menjadi hewan yang dominan disebabkan oleh adanya pohon kelapa, dan pohon buahbuahan yang ditanam pada lahan reklamasi selain itu adanya kebun kelapa sawit yang berada disekitar lahan reklamasi PT. RBT. Hal ini sesuai dengan penelitian Zamzami et al., (2019), bajing kelapa (Callosciurus notatus) makan serangga, buah-buahan, kacang-kacangan dan biji-bijian.

Mamalia ditemukan saat penelitian, secara keseluruhan tidak dilindungi berdasar Peraturan Menteri Lingkungan Hidup Dan Kehutanan No 106 (2018) . Berdasar status IUCN semua mamalia yang ditemukan Least Concern (LC; Berisiko Rendah) dan tidak terdapat dalam apendiks berdasar CITES (perdagangan satwa) (Tabel 6).

\section{KESIMPULAN}

Satwa reptil yang ditemukan sebanyak 7 jenis dengan keanekaragaman 1,36 termasuk sedang berdasar nilai indeks keanekaragaman Shannon-Wiener, sedangkan satwa amfibi ditemukan sebanyak 3 jenis dengan keanekaragaman sebesar 0,50 yang berdasar pada indeks keanekaragaman Shannon-Wiener adalah rendah. Satwa mamalia ditemukan sebanyak 4 jenis dengan keanekaragaman sebesar 1,12 yang berdasar pada nilai indeks keanekaragaman Shannon-Wiener termasuk keanekaragamannya sedang. 


\section{UCAPAN TERIMA KASIH}

Ucapan terima kasih kepada seluruh staff dan karyawan PT. RBT yang telah membantu sehingga karya ilmiah ini dapat diselesaikan.

\section{DAFTAR PUSTAKA}

Ariza, Y.S., Dewi, B.S., dan Darmawan, A. (2014). Keanekaragaman Jenis Amfibi (Ordo Anura) Pada Beberpa Tipe Habitat di Youth Camp Desa Hurun Kecamatan Padang Cermin Kabupaten Pesawaran. Jurnal Sylva Lestari, 2(1), 21-30.

Cogger, H.G. (1999). The Little Guide Reptiles and Amphinians. Fog City Press. San Francisco. USA.

Duellman, W.E., Trueb, L. (1986). Biology of Amphibians. Baltimore (UK): The Johns Hopkins University Press.

Goin, C.J,. Goin, O.B., Zug, G. (1978). Introduction to Herpetology. San Fransisco (US): WH Freeman and Company.

Hasibuan, R.S., Susdiyanti, T., \& Septiana, F. (2018). Keanekaragaman Burung dan Mamalia pada lahan reklamasi PT. Aneka Tambang Bogor, Jawa Barat. Ekologia, 18(1), 1-9.

Heyer, W.R., Donnelly, M.A., McDiarmid, R.W., Hayek, L. \& Foster, M.S. (1994). Measuring and Monitoring Biological Diversity.Standard Methods for Amphibians. Smithsonian Institution Press, Washington DC.

Kusrini, M. D. (2009). Pedoman Penelitian dan Survei Amfibi di Alam. In Fakultas Kehutanan IPB. Bogor.

Kwatrina, R. T. (2019). Keanekaragaman Spesies Herpetofauna Pada Berbagai Tipe Tutupan Lahan Di Lansekap Perkebunan
Sawit: Studi Kasus di PT. BLP Central Borneo. Jurnal Pengelolaan Sumberdaya Alam Dan Lingkungan (Journal of Natural Resources and Environmental Management), 9(2), 304-313. https://doi.org/10.29244/jpsl.9.2.304-313

Ludwig, J.A. and Reynolds, J. (1988). Statistical Ecology: A Primer on Methods and Computing. Wiley-Interscience Pub., New York.

Magurran, A.E. (1988). Ecological Diversity and It's Measurement. New Jersey: Princeton University Press.

Muslim, T dan Ulfah, K.S. (2016). Keanekaragaman Herpetofauna di Lahan Reklamasi Tambang Batubara PT Singlurus Pratama, Kalimantan Timur. Seminar Nasional Biologi, May.

Nurkharimah, A.B. (2019). Identifikasi Protozoa pada darah dan saluran pencernaan Biawak Air (Veranus salvator). Fakultas Kedokteran Hewan Universitas Airlangga.

Sanhayani, R., Supartono, T., \& Hendrayana, Y. (2019). Keanekaragaman jenis ordo anura di blok palutungan seksi pengelolaan taman nasional wilayah kuningan taman nasional gunung ciremai. Prosiding Semnas Pengembangan Sumber Daya Perdesaan Dan Kearifan Lokal Berkelanjutan IX", 1 , 93-101.

Subowo. (2011). Penambangan Sistem Terbuka Ramah Lingkungan Dan Upaya Reklamasi Pasca Tambang Untuk Memperbaiki Kualitas Sumberdaya Lahan Dan Hayati Tanah. Jurnal Sumberdaya Lahan, 5(2), 83-94.

Sukiya. (2003). Biologi Vertebrata. JICA. Malang: Universitas Negeri Malang.

Zamzami, Z. M., Riskyana,Wahyuni, P., Dewi, B.S. (2019). Keanekaragaman Satwa Liar Di KHDTK Getas. Journal of Tropical Upland Resources, 2(2), 269-275. 